\title{
Uraemia as a Determinant of Convulsions in Acute Infantile Hypernatraemia
}

\author{
J. B. P. STEPHENSON \\ From the University Department of Child Health, and Royal Hospital for Sick Children, Glasgow
}

\begin{abstract}
Stephenson, J. B. P. (1971). Archives of Disease in Childhood, 46, 676. Uraemia as a determinant of convulsions in acute infantile hypernatraemia. In a group of 57 infants with acute illness and hypernatraemia (sodium $150 \mathrm{mEq} / \mathrm{l}$. or over), convulsions occurred early in therapy in 17. Other common causes of convulsions had been eliminated as far as possible.

The incidence of convulsions was related to the degree of uraemia and acidaemia present on admission and not related to the sodium concentration. It is concluded that hypernatraemia, within the range studied, is not an important cause of infantile seizures unless other factors are operating. Elucidation of these other factors may be more profitable than study of the osmotic properties of the body fluids.
\end{abstract}

Though an association between infantile hypernatraemia and subsequent convulsions has been frequently reported (e.g. Rapoport, 1947; Finberg and Harrison, 1955; Macaulay and Blackhall, 1961; Morris-Jones, Houston, and Evans, 1967; and Bruck, Abal, and Aceto, 1968a and b), the nature of the association remains unclear. In his recent review of this topic, Finberg (1969) wrote 'considerably more investigation is in order to work out optimal modes of therapy, in particular, to determine more precisely what causes the post treatment convulsion and to obviate the contributing factors if possible'. The study to be reported was prompted by the clinical observation that hypernatraemia was often trivial in ill infants who convulsed during rehydration, while others with severe hypernatraemia, uncomplicated by uraemia, remained seizure free. In this retrospective investigation the relative contributions of varying degrees of hypernatraemia and uraemia to the incidence of post-treatment convulsions are compared in a population of infants in which other major causes of convulsions have been excluded as far as possible.

\section{Patients and Methods}

The study was confined to patients admitted to the Royal Hospital for Sick Children, Glasgow, during 1966 and 1967. Instances of hypernatraemia-defined as a serum (or plasma) sodium concentration of 150 $\mathrm{mEq} / \mathrm{l}$. or above (Harrison and Finberg, 1959)-were identified by a search of the records of the Department

Received 8 April 1971. of Pathological Biochemistry, and included 2 children in whom hypernatraemia had been established before transfer from another hospital. Clinical and laboratory data relating to the 134 admissions in which hypernatraemia was documented were transferred to punched cards.

Acute infantile hypernatraemia was defined by five criteria :

(1) Age not more than 365 days.

(2) Serum or plasma sodium equal to or greater than $150 \mathrm{mEq} / \mathrm{l}$. on testing the first blood sample obtained after admission to hospital.

(3) No (appreciable) quantity of intravenous fluid, and no sodium bicarbonate, had been administered before (2).

(4) The hypernatraemia (2) was discovered during investigation of an acute illness for which admission to hospital had been necessary.

(5) No chronic disease or malformation was suspected at the time of admission.

These criteria were satisfied in 99 admissions.

Because it was evident that several well-known 'causes' of convulsions were operating in this group, four further constraints were imposed in an attempt to eliminate them:

(6) Age 29 days or over.

(7) Temperature less than $41.1^{\circ} \mathrm{C}$ in the first 24 hours of admission.

(8) Convulsions not already present on arrival in hospital.

(9) Survival for more than 24 hours after admission or after onset of convulsions.

These limits were designed to exclude, respectively, neonatal tetany and other convulsive disorders of the newborn, malignant hyperpyrexia, pre-existing cerebral 
TABLE I

Statistical Analysis by Parametric and Non-parametric Methods of Biochemistry in 57 Infants with Acute Illness; Subsequent Convulsions are Associated with Uraemia and Acidaemia Rather than Increased Hypernatraemia

\begin{tabular}{|c|c|c|c|c|c|c|c|c|}
\hline \multirow{2}{*}{$\begin{array}{c}\text { Admission } \\
\text { Biochemistry }\end{array}$} & \multicolumn{2}{|c|}{ With Convulsions } & \multicolumn{2}{|c|}{ Without Convulsions } & \multicolumn{2}{|c|}{ t Test } & \multicolumn{2}{|c|}{ U Test } \\
\hline & No. & Mean \pm SD (Range) & No. & Mean \pm SD (Range) & $\mathbf{t}$ & $\mathbf{P}$ & $z$ & $\mathbf{P}$ \\
\hline Sodium (mEq/1.) & 17 & $\begin{array}{c}164 \cdot 7 \pm 10 \cdot 0 \\
(152-192)\end{array}$ & 40 & $\begin{array}{c}160 \cdot 2 \pm 8 \cdot 8 \\
(150-195)\end{array}$ & $1 \cdot 61$ & $>0.10$ & $1 \cdot 80$ & $\begin{array}{l}>0.05 \\
<0.10\end{array}$ \\
\hline & 17 & $\begin{array}{l}46 \cdot 1 \pm 20 \cdot 0 \\
(10 \cdot 0-78 \cdot 2)\end{array}$ & 40 & $\begin{array}{l}27 \cdot 0 \pm 12 \cdot 4 \\
(11 \cdot 7-61 \cdot 7)\end{array}$ & $\begin{array}{c}3.66 \\
\text { (d.f. }=21 \cdot 6)\end{array}$ & $<0.002^{\star}$ & $3 \cdot 53$ & $<0.001^{\star}$ \\
\hline$p H$ (units) & 17 & $\begin{array}{l}7 \cdot 13 \pm 0 \cdot 14 \\
(6 \cdot 78-7 \cdot 34)\end{array}$ & 40 & $\begin{array}{l}7 \cdot 24 \pm 0 \cdot 12 \\
(6 \cdot 95-7 \cdot 40)\end{array}$ & $\begin{array}{c}2 \cdot 85 \\
\text { (d.f. }=26 \cdot 5)\end{array}$ & $<0.01^{\star}$ & $2 \cdot 75$ & $<0.01^{\star}$ \\
\hline
\end{tabular}

$\star$ Statistically significant.

t See footnote.

disorder or primary encephalopathy, and agonal convulsions. In this retrospective study there were no valid means of excluding certain other biochemical causes of seizures, such as hypoglycaemia, because the relevant data were not available for all admissions. 57 infant admissions satisfied all 9 criteria, and are the subject of this investigation. Admission serum or plasma sodium and blood urea estimations were available in every case. Admission capillary blood $\mathrm{pH}$ by micro-Astrup method was known in $\mathbf{5 0}$ instances; in the remaining 7 it was derived from the blood bicarbonate, assuming a $\mathrm{PCO}_{2}$ of $40 \mathrm{mmHg}$, using the SiggaardAndersen nomogram.

The relation between the sodium, urea, and $p \mathrm{H}$ values, and the presence or absence of convulsions was investigated statistically by means of parametric ( $t$ test) and non-parametric ( $U$ test) methods. The $t$ test used was Welch's approximation throughout, because of the significant differences between the variances for urea in the two groups with and without convulsions. In the $U$ test a correction for ties has been applied. The notation used is that of Siegel (1956). Contingency tables with analysis by $\chi^{2}$ are presented as an alternative means of displaying the data. The significance levels (values of P) are for two-tailed tests throughout.

\section{Results}

Convulsions, often fragmentary, occurred after admission on 17 occasions. In only one case (sodium $192 \mathrm{mEq} / 1$. , blood urea $67 \mathrm{mmol} / 1 ., \dagger$ $p \mathrm{H} 7 \cdot 25)$ was the seizure delayed beyond the first 48 hours in hospital.

Beyond the chosen limit of $150 \mathrm{mEq} / 1$. there was no significant correlation between the degree of hypernatraemia and the incidence of subsequent convulsions in the 57 infants admitted with acute illness (Tables I and II). On the other hand the

tThe blood urea has been expressed throughout in $\mathrm{mmol} / \mathrm{l}$. (millimoles per litre). To convert to $\mathrm{mg} / 100 \mathrm{ml}$, multiply by 6 . (For example, $30 \mathrm{mmol} / 1$. $=180 \mathrm{mg} / 100 \mathrm{ml}$ ). To obtain a rough estimate of the osmolality, double the sodium concentration in $\mathrm{mEq} / \mathrm{l}$. and add the urea value in $\mathrm{mmol} / \mathrm{l}$.
TABLE II

Lack of Correlation Between Sodium Concentration and Incidence of Convulsions in Treatment

\begin{tabular}{c|c|c|c}
\hline $\begin{array}{c}\text { Serum Sodium } \\
(\mathrm{mEq} / 1 .)\end{array}$ & $\begin{array}{c}\text { With } \\
\text { Convulsions }\end{array}$ & $\begin{array}{c}\text { Without } \\
\text { Convulsions }\end{array}$ & Total \\
\hline $\begin{array}{c}\text { Con } \\
<158\end{array}$ & 13 & 22 & 35 \\
4 & 18 & 22 \\
\hline Total & 40 & 57 \\
\hline$\chi^{2}=1.57 ; P>0 \cdot 10$. & & \\
(Yates' modification.)
\end{tabular}

relation between the degree of uraemia and the incidence of later seizures was striking $(P<0.001)$ (Tables I and III). All 17 infants who convulsed had either a blood urea of $30 \mathrm{mmol} / 1$. or greater, or a $p \mathrm{H}$ of less than $7 \cdot 20$, or both.

There was no significant difference between the incidence of convulsions in those rehydrated intravenously (46 infants) and those given oral fluids (9 infants). In the group of 46 who had intravenous fluids, the association between blood urea and subsequent convulsions remained clear

TABLE III

Correlation Between Admission Blood Urea and Subsequent Convulsions

\begin{tabular}{c|c|c|c}
\hline $\begin{array}{c}\text { Blood Urea } \\
\text { (mmol/1.) }\end{array}$ & $\begin{array}{c}\text { With } \\
\text { Convulsions }\end{array}$ & $\begin{array}{c}\text { Without } \\
\text { Convulsions }\end{array}$ & Total \\
\hline$<30$ & 3 & 26 & 29 \\
$30-$ & 8 & 13 & 21 \\
$60-$ & 6 & 1 & 7 \\
\hline Total & 17 & 40 & 57 \\
\hline
\end{tabular}

$\chi^{2}=16.39 ;$ d.f. $=2 ; P<0.001$. 
cut $(P<0.001)$, while that between serum or plasma sodium and later seizures was still not significant $(P>0.05)$.

Of the 57 infants, 35 had diarrhoea and 22 did not. The findings with respect to convulsions, sodium, and urea did not differ in these subgroups from those of the total group, so they have not been described separately.

\section{Discussion}

These results suggest that the presence or absence of uraemia, and to a lesser extent acidaemia, is a major factor in determining whether an acutely ill infant will develop seizures during rehydration therapy. They do not support the notion that the degree of hypernatraemia is important in this respect, at least in the range studied, for, if so, one would expect to be able to produce a dose- or concentration-response curve, with seizure incidence climbing as sodium levels increased. MorrisJones et al. (1967) did in fact attempt to show this but had insufficient data (combined sodium and urea levels) for it to be clear whether or not this was a spurious correlation. In a careful prospective study of the therapy of hypernatraemic children, Bruck et al. (1968b) found no influence of sodium level on seizure incidence in their group B: when the sodium concentration was $160 \mathrm{mEq} / \mathrm{l}$. or less, 3 of 15 convulsed; when it was greater than 160 $\mathrm{mEq} / \mathrm{l}$., 4 of 14 convulsed.

The low incidence of seizures in infants with 'dehydration' but with normal serum sodium concentrations seems at first sight to argue against this thesis, but in practice such infants with normonatraemia seldom have severe uraemia. During the same two years as the present series, 50 infants under 1 year were admitted to the Royal Hospital for Sick Children with gastroenteritis and measured serum sodium concentration of less than $150 \mathrm{mEq} / \mathrm{l}$. Only 3 of these had a blood urea of $30 \mathrm{mmol} / \mathrm{l}$. or higher, 47 had lesser levels. From the results of the present investigation-showing that 14 of 28 $(50 \%)$ of those with blood urea equal to or greater than $30 \mathrm{mmol} / \mathrm{l}$. convulsed while only 3 of 29 $(10.5 \%)$ of those with a lower blood urea did soone could predict that there would be 6 episodes of convulsions during therapy among the 50 normonatraemic infants with gastroenteritis. In fact there were 5.

The suggestion that uraemia and acidaemia are of importance in the genesis of the seizures in hypernatraemia is strongly supported by analysis of the small number of cases forming group B of Bruck et al. (1968b). 7 of 14 children with a blood urea equal to or greater than $15 \mathrm{mmol} / \mathrm{l}$. convulsed while none of 15 with a lower level did so $(P<0.01$, Fisher test). Similarly, 7 of 12 with $p H$ less than $7 \cdot 1$ convulsed, compared with none of 17 whose $p H$ was equal to or greater than $7 \cdot 1(\mathrm{P}<0.01$, Fisher test). As mentioned earlier, the height of the sodium level seemed to play no part.

Experimental work on rehydration seizures in hypernatraemia has not shed much light on this aspect of their pathogenesis. The detailed studies of Hogan et al. (1969) did not include estimations of blood urea or $\mathrm{pH}$ but it is notable that there was no significant difference between the prehydration plasma sodium concentrations in those rabbits which convulsed (19 of 34) and in those which did not.

It has been argued (Morris-Jones et al., 1967) that uraemia contributes both to increased extracellular osmolality and to increased risk of convulsions, and by implication that it is the imposed alteration in the osmotic properties of the extracellular fluid, which results in the liability to seizures on rehydration. In fact there is little direct evidence to support this view. Though cerebral disturbances may occur during haemodialysis for urasmia (Rosen, O'Connor, and Shaldon, 1964), the fall of blood urea is much slower than this during simple rehydration, with a half-time of about 24 hours (data derived from the present series). Intuitively it seems likely that in the acutely uraemic infant it is not the osmotic properties of urea which are of paramount importance, but rather some other less easily measurable disturbances associated with the acute uraemia.

At present one can do little more than speculate on what is important in this regard. Excessive losses of potassium are common in these patients, whether or not there is diarrhoea (Weil and Wallace, 1956; Bruck et al., 1968a). In the experimental situation, Hogan et al. (1969) drew attention to the decreased potassium content of the brains of rehydrated rabbits which had convulsed, compared with those seizure free. Though the difference did not reach statistical significance, it was noted in all areas of brain sampled. Potassium is of course intimately involved in neuronal excitability and its role in the present clinical situation deserves further investigation. There is no evidence that increased urea production accompanies hypernatraemia, but it is known to occur in adults with heart failure (Domenet and Evans, 1969) and might well be expected also in ill, shocked infants, in which case it would serve as a signal of tissue vulnerability. Severe urea retention implies not only reduced renal blood flow, but impaired cerebral blood flow in addition. While initial 
brain shrinkage is a well-established phenomenon in experimental hypernatraemia, little is known of the mechanism of the considerable reduction in intracranial volume which is a regular feature of severe normonatraemic dehydration and well known to clinicians by its outward sign - the depressed fontanelle.

The distinction between simple acute hypernatraemia and that complicated by uraemia is important where therapy is concerned. Bruck et al. (1968b) have shown in a prospective trial, allocating one of two therapies by random numbers, that convulsions (which occurred only in uraemic children) could be prevented by the use of a polyionic infusion fluid containing per litre: sodium 57, potassium 25 , magnesium 6 , chloride 50 , lactate $25 \mathrm{mEq}$; phosphate 7 millimoles; and glucose 100 g. All but one of their patients had diarrhoea, and their results did not reach the $1 \%$ level of significance, so that further trial of their regimen is warranted. On the other hand if moderate hypernatraemia is found unaccompanied by uraemia and acidaemia, rehydration can often be accomplished by oral feeding (Ironside, Tuxford, and Heyworth, 1970). Severe isolated hypernatraemia-about 200 $\mathrm{mEq} / 1$. - has been successfully treated by peritoneal dialysis (Finberg, Kiley, and Luttrell, 1963) and by infusion of sodium-free fluid (personal observations). If convulsions do in fact occur during therapy, there is evidence that parenteral barbiturate or calcium gluconate is ineffective (Bruck et al., 1968b). Intravenous diazepam, however, has been successfully used in this situation (Bailey and Fenichel, 1968). In every case management must depend upon the complete clinical picture and should not be too greatly influenced by the level of the plasma sodium alone.

I thank Professor J. H. Hutchison and Dr. R. A. Shanks for permission to study their patients, Professor
Hutchison for stimulating the investigation, Professor H. G. Morgan and Dr. R. Logan for biochemical investigations, Mr. T. McCambridge for technical assistance, and Miss Rosemary Dalton of the University Department of Epidemiology and Preventative Medicine, for the statistical analysis.

\section{REFERENCES}

Bailey, D. W., and Fenichel, G. M. (1968). The treatment of prolonged seizure activity with intravenous diazepam. Fournal of Pediatrics, 73, 923.

Bruck, E., Abal, G., and Aceto, T., Jr. (1968a). Pathogenesis and pathophysiology of hypertonic dehydration with diarrhea. American Fournal of Diseases of Children, 115, 122.

Bruck, E., Abal, G., and Aceto, T., Jr. (1968b). Therapy of infants with hypertonic dehydration due to diarrhea. American Fournal of Diseases of Children, 115, 281.

Domenet, J. G., and Evans, D. W. (1969). Uraemia in congestive heart failure. Quarterly fournal of Medicine, 38, 117.

Finberg, L. (1969). Hypernatremic dehydration. Advances in Pediatrics, 16, 325.

Finberg, L., and Harrison, H. E. (1955). Hypernatremia in infants. Pediatrics, 16, 1.

Finberg, L., Kiley, J., and Luttrell, C. N. (1963). Mass accidental salt poisoning in infancy. Fournal of the American Medical Association, 184, 187.

Harrison, H. E., and Finberg, L. (1959). Hypernatremic dehydration. Pediatric Clinics of North America, 6, 193.

Hogan, G. R., Dodge, P. R., Gill, S. R., Master, S., and Sotos, J. F. (1969). Pathogenesis of seizures occurring during restoration of plasma tonicity to normal in animals previously chronically hypernatremic. Pediatrics, 43, 54.

Ironside, A. G., Tuxford, A. F., and Heyworth, B. (1970). A survey of infantile gastroenteritis. British Medical fournal, 3, 20.

Macaulay, D., and Blackhall, M. I. (1961). Hypernatraemic dehydration in infantile gastroenteritis. Archives of Disease in Childhood, 36, 543.

Morris-Jones, P. H., Houston, I. S., and Evans, R. C. (1967) Prognosis of the neurological complications of acute hypernatraemia. Lancet, 2, 1385.

Rapoport, S. (1947). Hyperosmolarity and hyperelectrolytemia in pathologic conditions of childhood. American fournal of Diseases of Children, 74, 682.

Rosen, S. M., O'Connor, K., and Shaldon, S. (1964). Haemodialysis disequilibrium. British Medical fournal, 2, 672.

Siegel, S. (1956). Nonparametric Statistics for the Behavioral Sciences. McGraw-Hill, New York.

Weil, W. B., and Wallace, W. M. (1956). Hypertonic dehydration in infancy. Pediatrics, 17, 171.

Correspondence to Dr. J. B. P. Stephenson, Royal Hospital for Sick Children, Glasgow C.4. 